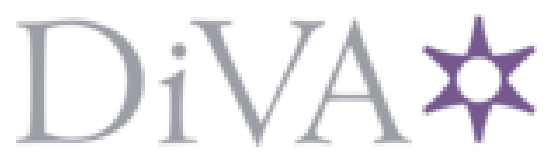

http://www.diva-portal.org

This is the published version of a paper published in Zeitschrift für Naturforschung. $B, A$ journal of chemical sciences.

Citation for the original published paper (version of record):

Legrand, S., Nordlander, G., Nordenhem, H., Borg-Karlson, A K., Unelius, C R. (2004) Hydroxy-methoxybenzoic methyl esters: Synthesis and antifeedant activity on the pine weevil, Hylobius abietis

Zeitschrift für Naturforschung. B, A journal of chemical sciences, 59(7): 829-835 https://doi.org/10.1515/znb-2004-0714

Access to the published version may require subscription.

N.B. When citing this work, cite the original published paper.

Permanent link to this version:

http://urn.kb.se/resolve?urn=urn:nbn:se:Inu:diva-14128 


\title{
Hydroxy-Methoxybenzoic Methyl Esters: Synthesis and Antifeedant Activity on the Pine Weevil, Hylobius abietis
}

\author{
Sacha Legrand ${ }^{\mathrm{a}}$, Göran Nordlander ${ }^{\mathrm{b}}$, Henrik Nordenhem ${ }^{\mathrm{b}}$, Anna-Karin Borg-Karlson ${ }^{\mathrm{c}}$, \\ and C. Rikard Unelius ${ }^{\mathrm{a}}$ \\ ${ }^{a}$ Department of Chemistry and Biomedical Sciences, University of Kalmar, \\ SE-391 82 Kalmar, Sweden \\ ${ }^{b}$ Department of Entomology, Swedish University of Agricultural Sciences, \\ P.O. Box 7044, SE-750 07 Uppsala, Sweden \\ c Department of Chemistry, Organic Chemistry, Royal Institute of Technology, \\ SE-100 44 Stockholm, Sweden \\ Reprint requests to Associate Prof. C. Rikard Unelius. Fax: +46 480446262. \\ E-mail: rikard.unelius@hik.se
}

Z. Naturforsch. 59b, 829 - 835 (2004); received December 15, 2003

The pine weevil Hylobius abietis (L.) (Coleoptera: Curculionidae) feeds on the bark of coniferous seedlings and is the economically most important forestry restocking pest in large parts of Europe. Substances with an antifeedant effect may offer an environmentally friendly alternative to insecticides for the protection of planted seedlings. Bioassays were performed on commercial and synthetic methyl hydroxy-methoxybenzoates in order to determine their possible antifeedant activity.

Two methyl hydroxy-methoxybenzoates were synthesized by esterification and mono- $O$-methylation of two dihydroxybenzoic acids. A regioselective protection-deprotection strategy was used in the synthetic pathway of the other non-commercial esters, esterification and selective pivaloylation of the less-hindered hydroxyl group of other commercial dihydroxybenzoic acids gave diester intermediates, which then were $O$-methylated before methanolysis of the pivaloyl group which yielded the desired non-commercial methyl hydroxy-methoxybenzoates.

The five synthesized methyl hydroxy-methoxybenzoic esters were complemented with commercial samples of the five other isomers of methyl hydroxy-methoxybenzoate and spectrometric data were collected for the complete set of isomers. All ten isomers were tested for their antifeedant effect on the pine weevil. The effect varied considerably among the hydroxy-methoxybenzoic esters. Methyl 2-hydroxy-3-methoxybenzoate showed the highest effect and may thus be a candidate for practical use in pine weevil pest management.

Key words: Methyl Hydroxy-methoxybenzoates, Antifeedant Activity, Hylobius abietis

\section{Introduction}

Adult pine weevils, Hylobius abietis (L.), frequently kill planted conifer seedlings by their feeding on the stem bark. Unprotected seedlings commonly suffer over $80 \%$ mortality in regions with managed coniferous forests [1]. To protect the seedlings it is common practice in many European countries to routinely treat transplants with an insecticide. Because of environmental hazards and health risks for forest workers the usage of insecticides is seriously questioned today. Possibly, antifeedant substances applied to transplants could offer an alternative to insecticides [2].

Recently we have shown that various benzoate derivatives have strong antifeedant effect on the pine weevil [3]. This encouraged further studies of com- pounds related to benzoic acid. In this study, we investigated the potential of hydroxy-methoxy acid methyl esters as antifeedants useful for the protection of planted seedlings against pine weevil damage. There are 10 possible isomers of methyl hydroxymethoxybenzoate (Scheme 1). The esters $\mathbf{1 - 5}$ had to be synthesized while the esters 6-10 were commercially available.

The esters 1, 2,3 and 4 are intermediates in the total synthesis of compounds with important biological effects and their synthesis have been reported previously [4]. The synthesis of methyl 5-hydroxy-2methoxybenzoate (5) was published in 1983 by Harwood [5].

The methyl benzoic esters $\mathbf{1}$ and $\mathbf{2}$ were synthesized based on the method described by Chakraborty 
<smiles>COc1cccc(O)c1OC</smiles><smiles>COC(=O)c1c(O)cccc1OC</smiles>

Methyl 2-hydroxy-6-methoxybenzoate

1<smiles>COC(=O)c1cc(O)cc(OC)c1</smiles>

Methyl 3-hydroxy-5-methoxybenzoate 2
Methyl 3-hydroxy-2-methoxybenzoate

3

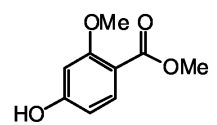

Methyl 4-hydroxy-2-methoxybenzoate

4<smiles>COC(=O)c1cc(O)ccc1OC</smiles>

Methyl 5-hydroxy-2-methoxybenzoate

5<smiles>O=C(O)c1ccc(O)cc1O</smiles>

Methyl 2-hydroxy-4-methoxybenzoate

6<smiles>COC(=O)c1ccc(OC)c(O)c1</smiles>

Methyl 3-hydroxy-4-methoxybenzoate

7

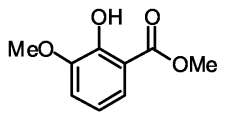

ethyl 4-hydroxy-3-methoxybenzoate

Methyl 2-hydroxy-3-methoxybenzoate

Scheme 1. All isomers of methyl hydroxy-methoxybenzoate $(\mathbf{1 - 1 0})$.

et al. [4b]. The corresponding acids of $\mathbf{1}$ and $\mathbf{2}$ were esterified and mono- $O$-methylated (Scheme 2). The regioselective protection presented by Dornhagen and Scharf in their synthesis of the dichloroisoeverninic acid [6] was used as a basis for our synthesis of the methyl benzoates 3, 4 and 5 (Scheme 3). Our synthesis started by esterification of the benzoic acids 15a, 15b and 15c. Acylation of the synthesized esters 16a, 16b and 16c occurred only at the less-hindered hydroxyl group (OH group meta or para to the ester group). $O$ methylation of the ortho-OH group, followed by deprotection of the diesters gave the desired methyl benzoic esters $\mathbf{3 , 4}$ and $\mathbf{5}$.

\section{Results and Discussion}

Methyl 2-hydroxy-6-methoxybenzoate (1) and methyl 3-hydroxy-5-methoxybenzoate (2) were synthesized from the commercially available benzoic acids 11 and 13 (Scheme 2). It was found that the esterification of the carboxylic acid 11 with $\mathrm{MeOH}$ and $\mathrm{H}_{2} \mathrm{SO}_{4}$ as reactants gave the ester $\mathbf{1 2}$ in very low yield. The low reactivity of the $\mathrm{COOH}$ group in $\mathbf{1 1}$ is presumably due to the resonance effect of two hydroxyl groups ortho to $\mathrm{COOH}$. The yield of this esterification reaction was improved when the compound 11 was treated with dicyclocarbodiimide (DCC) and dimethylaminopyridine (DMAP) in a $\mathrm{MeOH} / \mathrm{CH}_{2} \mathrm{Cl}_{2}$ mixture. The esterification conditions
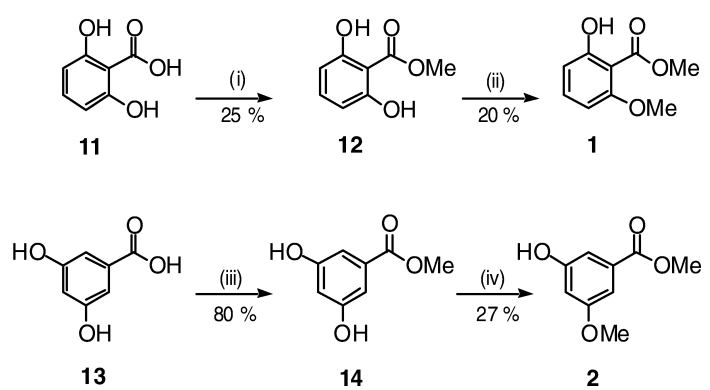

Scheme 2. Reaction conditions: (i) DCC, MeOH, DMAP, $\mathrm{CH}_{2} \mathrm{Cl}_{2}$, RT; (ii) $\mathrm{MeI}, \mathrm{K}_{2} \mathrm{CO}_{3}, \mathrm{DMF}, 35^{\circ} \mathrm{C}$; (iii) $\mathrm{MeOH}$, $\mathrm{H}_{2} \mathrm{SO}_{4}$, reflux; (iv) MeI, $\mathrm{MeOH}, \mathrm{K}_{2} \mathrm{CO}_{3}$, RT.

were more effective in this case since the carboxylic acid was converted to a compound with a better leaving group. It was noted that the treatment of the meta disubstituted benzoic acid $\mathbf{1 3}$ with an excess of $\mathrm{MeOH}$ and a catalytic amount of $\mathrm{H}_{2} \mathrm{SO}_{4}$ afforded the ester 14 in good yield, due to the absence of resonance effects with the $\mathrm{COOH}$ group. The products 12 and 14 were then mono- $O$-methylated by use of methyl iodide in the presence of a weak base.

A regioselective protection [6] was the key step in the syntheses of the methyl benzoates $\mathbf{3}, \mathbf{4}$ and $\mathbf{5}$ (Scheme 3). After esterification of the commercially available benzoic acids $15 \mathbf{a}, \mathbf{1 5 b}$ or $15 \mathbf{c}$, it was found that the esters 16a, 16b or 16c when reacted with trimethylacetyl chloride, selectively yielded the intermediates $17 \mathbf{a}, \mathbf{1 7 b}$ or $\mathbf{1 7 c}$. 


\begin{tabular}{llcccc}
\hline No & Compound & $\begin{array}{c}\text { Index } \\
(6 \mathrm{~h})\end{array}$ & $\begin{array}{c}\text { Level of } \\
\text { significance }\end{array}$ & $\begin{array}{c}\text { Index } \\
(24 \mathrm{~h})\end{array}$ & $\begin{array}{c}\text { Level of } \\
\text { significance }\end{array}$ \\
\hline $\mathbf{1}$ & Methyl 2-hydroxy-6-methoxybenzoate & 94 & $* * *$ & 54 & $* * *$ \\
$\mathbf{2}$ & Methyl 3-hydroxy-5-methoxybenzoate & 35 & $* * *$ & 26 & $* * *$ \\
$\mathbf{3}$ & Methyl 3-hydroxy-2-methoxybenzoate & 77 & $* * *$ & 35 & $* * *$ \\
$\mathbf{4}$ & Methyl 4-hydroxy-2-methoxybenzoate & 69 & $* * *$ & 4 & $\mathrm{~ns}$ \\
$\mathbf{5}$ & Methyl 5-hydroxy-2-methoxybenzoate & 4 & $\mathrm{~ns}$ & -3 & $\mathrm{~ns}$ \\
$\mathbf{6}$ & Methyl 2-hydroxy-4-methoxybenzoate & 100 & $* * *$ & 52 & $* * *$ \\
$\mathbf{7}$ & Methyl 3-hydroxy-4-methoxybenzoate & 69 & $* * *$ & 32 & $* * *$ \\
$\mathbf{8}$ & Methyl 2-hydroxy-3-methoxybenzoate & 100 & $* * *$ & 85 & $* * *$ \\
$\mathbf{9}$ & Methyl 2-hydroxy-5-methoxybenzoate & 93 & $* * *$ & 56 & $* * *$ \\
$\mathbf{1 0}$ & Methyl 4-hydroxy-3-methoxybenzoate & 56 & $* * *$ & 22 & $*$ \\
\hline
\end{tabular}

Table 1. Effect of the ten benzoates on bark feeding by the pine weevil Hylobius abietis, as measured by the antifeedant index ( 0 is no activity, 100 is complete feeding deterrence).

$*=\mathrm{p}<0.05, \quad * *=\mathrm{p}<0.01$, $* * *=\mathrm{p}<0.001$ (Fisher exact test of a $2 \times 2$ table).
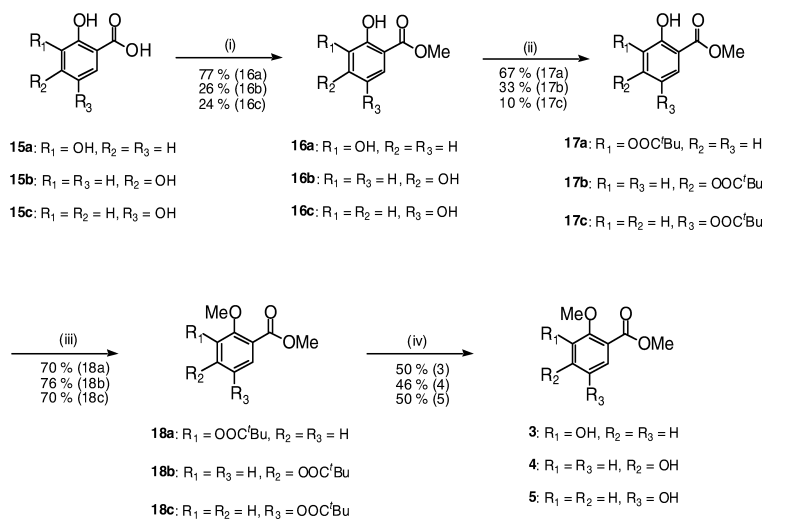

Scheme 3. Reaction conditions: (i) $\mathrm{MeOH}, \mathrm{H}_{2} \mathrm{SO}_{4}$, reflux; (ii) trimethylacetyl chloride, pyridine, $\mathrm{CH}_{2} \mathrm{Cl}_{2},-10{ }^{\circ} \mathrm{C}$ to RT; (iii) MeI, $\mathrm{K}_{2} \mathrm{CO}_{3}$, DMF, $35^{\circ} \mathrm{C}$; (iv) $\mathrm{MeOH}, \mathrm{K}_{2} \mathrm{CO}_{3}$, RT.

Due to the steric hindrance between the bulky protecting group, ${ }^{t} \mathrm{Bu}$, and the ester moiety, acylation was predominant at hydroxyl groups meta and para to the carbomethoxy group and not with the hydroxyl group ortho. $O$-methylation of the hydroxyl group ortho to the carbomethoxy group gave the compounds 18a, 18b or 18c. Then, the hydroxyl groups meta or para to the carbomethoxy group were deprotected using $\mathrm{MeOH} / \mathrm{K}_{2} \mathrm{CO}_{3}$, yielding the desired methyl benzoates $\mathbf{3}, \mathbf{4}$ or $\mathbf{5}$.

In conclusion, the synthesis of all non-commercial methyl hydroxy-methoxybenzoate was presented. Starting from the benzoic esters 11 and 13, the methyl esters $\mathbf{1}$ and $\mathbf{2}$ were synthesized in two steps. A regioselective protection was the critical step in the syntheses of the other methyl benzoates 3, 4 and $\mathbf{5}$.

The spectroscopic data of the commercially available methyl benzoates $6,7,8,9$ and 10 were also recorded. Interestingly, we noted that the mass spectra of all 2-hydroxy-isomers have a strong $\mathrm{m} / \mathrm{z} 150$ i.e. loss of methanol (32), while all other isomers have a strong 151 fragment. The mechanism for the loss

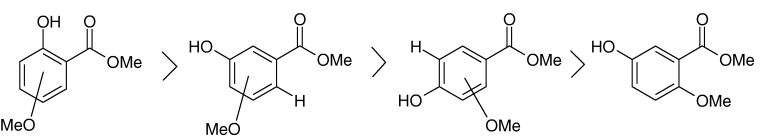

Scheme 4. Structure - activity relationships (decreasing activity from left to right).

of methanol can be explained by a rearrangement between the methylcarboxylate moiety and a hydroxyl hydrogen in ortho-position [7].

Bioassays were performed with all esters in order to determine their possible antifeedant effect against the pine weevil. Eight of the ten compounds showed antifeedant activity after $24 \mathrm{~h}$ exposure to pine weevils in the bioassay (Table 1). Only compounds $\mathbf{4}$ and $\mathbf{5}$ did not inhibit feeding over the $24 \mathrm{~h}$ period, although 4 showed activity after $6 \mathrm{~h}$. The most potent antifeedant among these compounds was $\mathbf{8}$. It was closely followed in activity by compounds $\mathbf{9}, \mathbf{1}$, and $\mathbf{6}$, and thereafter $\mathbf{3}$ and 7. Compound $\mathbf{2}$ and, particularly, $\mathbf{1 0}$ had only a weak effect.

Apparently, isomers with a hydroxy group in the ortho position have a stronger antifeedant effect (Scheme 4). The most potent compound (8) gave a somewhat higher index value after $24 \mathrm{~h}$ than shown by the strongest antifeedant compound (ethyl cinnamate) recently isolated from bark of Pinus contorta [2].

\section{Conclusion}

Starting from commercially available hydroxymethoxybenzoic acids, all non-commercial methyl hydroxy-methoxybenzoates were synthesized. Among the methyl hydroxy-methoxybenzoic esters tested in the bioassay, methyl 2-hydroxy-3-methoxybenzoate had the strongest antifeedant effect on adult pine weevils. A comparison with previously discovered antifeedants indicates that methyl 2-hydroxy-3-methoxybenzoate has potential for use in practical protection of conifer transplants. Further synthesis and bioassays 
are needed to predict the optimal structure for maximal antifeedant activity. More comparisons of similar compounds are also needed before structure - activity patterns can be properly discussed.

\section{Experimental Section}

Synthesis: General synthetic methodology

Melting points were determined on a Büchi 510 instrument and were not corrected. Preparative chromatography [8] and flash chromatography were done on silica gel (Merck 60). NMR spectra were recorded on spectrometers Bruker AC $250\left(250 \mathrm{MHz}\right.$ for ${ }^{1} \mathrm{H}$ and $63 \mathrm{MHz}$ for $\left.{ }^{13} \mathrm{C}\right)$ and Bruker AMX $500\left(500 \mathrm{MHz}\right.$ for ${ }^{1} \mathrm{H}$ and $125 \mathrm{MHz}$ for $\left.{ }^{13} \mathrm{C}\right)$. $\mathrm{CDCl}_{3}$ and DMSO- $d_{6}$ were used as solvents and the signals of the solvents served as internal standards. Chemical shifts were expressed in ppm, followed by multiplicity (s, singlet; $\mathrm{t}$, triplet; d, doublet; $\mathrm{m}$, multiplet; b, broad) and number of protons. Mass spectra of positive ions obtained by electron impact (EI, $70 \mathrm{eV}$ ) were measured on Hewlett-Packard or Varian Saturn ws GC-MS instruments.

Dimethylformamide (DMF) was distilled under $\mathrm{N}_{2}$ before use. Pyridine and $\mathrm{CH}_{2} \mathrm{Cl}_{2}$ were dried over $4 \AA$ molecular sieves. The starting materials employed were purchased from commercial suppliers and were used without further purification.

Methyl 2,6-dihydroxybenzoate (12): 2,6-Dihydroxybenzoic acid (11) $(1.00 \mathrm{~g}, 6.49 \mathrm{mmol})$ was dissolved in $\mathrm{MeOH}$ $(10 \mathrm{ml})$ and $\mathrm{CH}_{2} \mathrm{Cl}_{2}(65 \mathrm{ml})$ was added to the reaction mixture. DCC (1,3-dicyclohexylcarbodiimide) (1.49 g, $7.14 \mathrm{mmol}$ ) and DMAP (4-dimethylaminopyridine) (0.158 g, $1.30 \mathrm{mmol}$ ) were added and the reaction mixture was stirred at room temperature (RT) for $72 \mathrm{~h}$. The white precipitate was then removed by filtration and the solvents were evaporated. The crude product was purified by flash chromatography on silica gel, using cyclohexane-EtOAc (3:2) as eluent, to give $12(277 \mathrm{mg}, 25 \%)$ as a white solid. M.p. $58-$ $60{ }^{\circ} \mathrm{C} .-{ }^{1} \mathrm{H}$ NMR $\left(250 \mathrm{MHz}, \mathrm{DMSO}-d_{6}\right): \delta=3.78(\mathrm{~s}$, $3 \mathrm{H}, \mathrm{COOMe}), 6.32-6.35\left(\mathrm{~d}, 2 \mathrm{H}, 2 \times \mathrm{H}_{\mathrm{ar}}\right) 7.05-7.12$ (t, $\left.1 \mathrm{H}, \mathrm{H}_{\mathrm{ar}}\right), 9.94(\mathrm{bs}, 2 \mathrm{H}, \mathrm{OH}) .-{ }^{13} \mathrm{C}\left\{{ }^{1} \mathrm{H}\right\} \mathrm{NMR}(62.9 \mathrm{MHz}$, DMSO- $\left.d_{6}\right): \delta=51.76(\mathrm{COOMe}), 106.60\left(2 \times \mathrm{C}_{\mathrm{ar}}\right), 106.88$, 132.27, 157.22, 157.24, 168.17 (all $\mathrm{C}_{\mathrm{ar}}$ and $\mathrm{C}=\mathrm{O}$ ). $-\mathrm{MS}$ : $m / z=168\left[\mathrm{M}^{+}\right], 153,136(100 \%), 108,96,80,69,63,52$, 44, 39.

Methyl 2-hydroxy-6-methoxybenzoate (1): Methyl 2,6-dihydroxybenzoate (12) $(260 \mathrm{mg}, 1.55 \mathrm{mmol})$ was dissolved in DMF (2 ml) and $\mathrm{K}_{2} \mathrm{CO}_{3}(256 \mathrm{mg}, 1.86 \mathrm{mmol})$ was added in 2 portions, followed by MeI $(0.12 \mathrm{ml}, 1.94 \mathrm{mmol})$. The resulting suspension was vigorously stirred at $35{ }^{\circ} \mathrm{C}$ for $3 \mathrm{~h}$. The reaction mixture was then cooled to room temperature, the solid was removed by filtration and the solvent was evaporated to give a brown oil. The crude oil was purified by two flash chromatography procedures using cyclohexane-ethyl acetate (EtOAc) (2:3) and cyclohexaneEtOAc (4:1) as eluents. Compound 1 was isolated as a white solid (55 mg, 20\%). M.p. $50{ }^{\circ} \mathrm{C}$. $-{ }^{1} \mathrm{H}$ NMR (250 MHz, DMSO- $d_{6}$ ): $\delta=3.71$ (s, $3 \mathrm{H}, \mathrm{OMe}$ ), 3.73 (s, $3 \mathrm{H}, \mathrm{COOMe}$ ), 6.47-6.51 (d, $\left.2 \mathrm{H}, 2 \times \mathrm{H}_{\mathrm{ar}}\right), 7.14-7.21\left(\mathrm{t}, 1 \mathrm{H}, \mathrm{H}_{\mathrm{ar}}\right), 9.98$ (bs, $1 \mathrm{H}, \mathrm{OH}) .-{ }^{13} \mathrm{C}\left\{{ }^{1} \mathrm{H}\right\}$ NMR $\left(62.9 \mathrm{MHz}, \mathrm{DMSO}-d_{6}\right)$ : $\delta=51.64$ (COOMe), 55.54 (OMe) 101.84, 106.59, 108.38, 130.87, 155.32, 157.03, 166.52 (all $\mathrm{C}_{\mathrm{ar}}$ and $\mathrm{C}=\mathrm{O}$ ). - MS: $m / z(\%)=182(38)\left[\mathrm{M}^{+}\right], 150(100), 136(5.7), 122(31)$, 107 (55), 93 (2.9), 79 (5.3), 65 (5.3), 51 (4.3), 39 (4.3).

Methyl 3,5-dihydroxybenzoate (14): 3,5-Dihydroxybenzoic acid (13) $(1.00 \mathrm{~g}, 6.49 \mathrm{mmol})$ was dissolved in $\mathrm{MeOH}$ (40 ml) and some drops of $\mathrm{H}_{2} \mathrm{SO}_{4}$ were slowly added to the reaction mixture, which was stirred at reflux temperature. The reaction was monitored by TLC. When the reaction was finished, the solvent was evaporated and the crude product was dissolved in EtOAc and washed twice with brine. The organic layer was dried over $\mathrm{MgSO}_{4}$ and the solvent was evaporated to give $\mathbf{1 4}$ as a white powder (871 mg, 80\%). M.p. $165-168{ }^{\circ} \mathrm{C} .-{ }^{1} \mathrm{H}$ NMR $\left(250 \mathrm{MHz}, \mathrm{DMSO}-d_{6}\right): \delta=3.78$ (s, $3 \mathrm{H}, \mathrm{COOMe}), 6.43\left(\mathrm{~m}, 1 \mathrm{H}, \mathrm{H}_{\mathrm{ar}}\right), 6.80\left(\mathrm{~m}, 2 \mathrm{H}, 2 \times \mathrm{H}_{\mathrm{ar}}\right)$, $9.64(\mathrm{~s}, 2 \mathrm{H}, \mathrm{OH}) .-{ }^{13} \mathrm{C}\left\{{ }^{1} \mathrm{H}\right\}$ NMR $(62.9 \mathrm{MHz}$, DMSO$\left.d_{6}\right): \delta=51.85(\mathrm{COOMe}), 106.95\left(2 \times \mathrm{C}_{\mathrm{ar}}\right), 107.04,131.16$ (all $\left.\mathrm{C}_{\mathrm{ar}}\right), 158.41\left(2 \times \mathrm{C}_{\mathrm{ar}}\right), 166.12(\mathrm{C}=\mathrm{O}) .-\mathrm{MS}: m / z=168$ $\left[\mathrm{M}^{+}\right], 137$ (100\%), 109, 95, 81, 69, 53, 44.

Methyl 3-hydroxy-5-methoxybenzoate (2): Methyl 3,5-dihydroxybenzoate (14) (300 $\mathrm{mg}, 1.78 \mathrm{mmol})$ was dissolved in $\mathrm{MeOH}, \mathrm{K}_{2} \mathrm{CO}_{3}(296 \mathrm{mg}, 2.14 \mathrm{mmol}$ ) was added and the reaction mixture was stirred for a couple of minutes. MeI $(0.11 \mathrm{ml}, 1.78 \mathrm{mmol})$ was then added and the mixture was stirred at room temperature overnight. Silica gel was then added and the solvent was evaporated. After drying, the impregnated silica gel was put on top of a chromatography column and subjected to medium pressure liquid chromatography (MPLC, cyclohexane:EtOAc 70:30) to give $\mathbf{2}$ as a white powder $(70 \mathrm{mg}, 21 \%)$. M.p. $82-84{ }^{\circ} \mathrm{C} .-{ }^{1} \mathrm{H}$ NMR (250 MHz, DMSO- $\left.d_{6}\right): \delta=3.75$ (s, $\left.3 \mathrm{H}, \mathrm{COOMe}\right), 3.82$ (s, $3 \mathrm{H}, \mathrm{OMe}), 6.58\left(\mathrm{~s}, 1 \mathrm{H}, \mathrm{H}_{\mathrm{ar}}\right), 6.91\left(\mathrm{~s}, 1 \mathrm{H}, \mathrm{H}_{\mathrm{ar}}\right), 6.97$ (s, $\left.1 \mathrm{H}, \mathrm{H}_{\mathrm{ar}}\right), 9.87(\mathrm{~s}, 1 \mathrm{H}, \mathrm{OH}) .-{ }^{13} \mathrm{C}\left\{{ }^{1} \mathrm{H}\right\} \mathrm{NMR}(62.9 \mathrm{MHz}$, DMSO- $\left.d_{6}\right): \delta=52.04(\mathrm{COOMe}), 55.15(\mathrm{OMe}), 104.99$, 105.99, 108.54, 131.35, 158.53, 160.35, 165.95 (all $\mathrm{C}_{\mathrm{ar}}$ and $\mathrm{C}=\mathrm{O}) .-\mathrm{MS}: m / z(\%)=182(93)\left[\mathrm{M}^{+}\right], 167$ (1), $151(100)$, 136 (2.9), 123 (34), 108 (22), 93 (8.6), 79 (3.3), 69 (16), 63 (4.8), 51 (4.8), 44 (9), 39 (3.8).

Methyl 2,3-dihydroxybenzoate (16a): Prepared by the procedure used for compound 14 but with 2,3-dihydroxybenzoic acid (15a) (1.50 g, $9.8 \mathrm{mmol})$ as starting material. 16a was isolated as a slightly brown solid (1.27 g, 77\%). M.p. $68-$ $71{ }^{\circ} \mathrm{C} .-{ }^{1} \mathrm{H}$ NMR $\left(250 \mathrm{MHz}, \mathrm{DMSO}-d_{6}\right): \delta=3.88(\mathrm{~s}, 3 \mathrm{H}$, COOMe), $6.75\left(\mathrm{~m}, 1 \mathrm{H}, \mathrm{H}_{\mathrm{ar}}\right), 7.01\left(\mathrm{~m}, 1 \mathrm{H}, \mathrm{H}_{\mathrm{ar}}\right), 7.22(\mathrm{~m}$, $\left.1 \mathrm{H}, \mathrm{H}_{\mathrm{ar}}\right), 9.44$ (s, $\left.1 \mathrm{H}, \mathrm{OH}\right), 10.41(\mathrm{~s}, 1 \mathrm{H}, \mathrm{OH}) .-{ }^{13} \mathrm{C}\left\{{ }^{1} \mathrm{H}\right\}$ NMR (62.9 MHz, DMSO- $\left.d_{6}\right): \delta=52.30(\mathrm{COOMe}), 112.96$, $118.81,119.42,120.58,145.97,149.26,169.71$ (all $\mathrm{C}_{\mathrm{ar}}$ and 
$\mathrm{C}=\mathrm{O}) . \mathrm{MS}: m / z=168\left[\mathrm{M}^{+}\right], 153,136(100 \%), 119,108$, 91, 80, 63, 52, 44, 39.

Methyl 2,4-dihydroxybenzoate (16b): Prepared by the same procedure as compound $\mathbf{1 4}$ but with 2,4-dihydroxybenzoic acid 15b $(5.00 \mathrm{~g}, 32.44 \mathrm{mmol})$ as starting material. The crude product was purified by flash chromatography on silica gel using cyclohexane-EtOAc (80:20) as eluent. A white solid 16b (1.43 g, 26\%) was obtained. M.p. $115-118{ }^{\circ} \mathrm{C} .-{ }^{1} \mathrm{H}$ NMR $\left(250 \mathrm{MHz}, \mathrm{DMSO}-d_{6}\right): \delta=3.83$ (s, $3 \mathrm{H}, \mathrm{COOMe}), 6.29-6.30\left(\mathrm{~d}, 1 \mathrm{H}, \mathrm{H}_{\mathrm{ar}}\right), 6.34-6.38$ (dd, $\left.1 \mathrm{H}, \mathrm{H}_{\mathrm{ar}}\right), 7.61-7.65\left(\mathrm{~d}, 1 \mathrm{H}, \mathrm{H}_{\mathrm{ar}}\right), 10.46(\mathrm{~s}, 1 \mathrm{H}, \mathrm{OH})$, $10.71(\mathrm{~s}, 1 \mathrm{H}, \mathrm{OH}) .-{ }^{13} \mathrm{C}\left\{{ }^{1} \mathrm{H}\right\}$ NMR $(62.9 \mathrm{MHz}, \mathrm{DMSO}-$ $\left.d_{6}\right): \delta=51.90$ (COOMe), 102.36, 103.86, 108.24, 131.50, 162.58, 164.11, 169.46 (all $\mathrm{C}_{\mathrm{ar}}$ and $\mathrm{C}=\mathrm{O}$ ). $-\mathrm{MS}: m / z=168$ $\left[\mathrm{M}^{+}\right], 136(100 \%), 125,108,95,80,69,63,53,44,39$.

Methyl 2,5-dihydroxybenzoate (16c): Prepared by the procedure used for compound 14 but with 2,5-dihydroxybenzoic acid 15c (3.00 g, $19.4 \mathrm{mmol}$ ) as starting material. 16c was isolated as a white solid $(0.78 \mathrm{~g}, 24 \%)$. M.p. $73-$ $76{ }^{\circ} \mathrm{C} .-{ }^{1} \mathrm{H}$ NMR $\left(250 \mathrm{MHz}, \mathrm{DMSO}-d_{6}\right): \delta=3.87(\mathrm{~s}$, $3 \mathrm{H}, \mathrm{COOMe}), 6.76-6.83\left(\mathrm{~m}, 1 \mathrm{H}, \mathrm{H}_{\mathrm{ar}}\right), 6.93-6.99(\mathrm{~m}$, $\left.1 \mathrm{H}, \mathrm{H}_{\mathrm{ar}}\right), 7.14\left(\mathrm{~m}, 1 \mathrm{H}, \mathrm{H}_{\mathrm{ar}}\right), 9.18$ (s (apparent d), $1 \mathrm{H}$, $\mathrm{OH}), 9.85$ (bs, $1 \mathrm{H}, \mathrm{OH}) .-{ }^{13} \mathrm{C}\left\{{ }^{1} \mathrm{H}\right\}$ NMR $(62.9 \mathrm{MHz}$, DMSO- $\left.d_{6}\right): \delta=52.32(\mathrm{COOMe}), 114.01,117.63,123.74$, 149.47, 153.02, 153.97, 171.61 (all $\mathrm{C}_{\mathrm{ar}}$ and $\mathrm{C}=\mathrm{O}$ ). - MS: $m / z=168\left[\mathrm{M}^{+}\right], 136,108,80,69,53,44$.

Methyl 2-hydroxy-3-pivaloyloxybenzoate (17a): Methyl benzoate $16 \mathrm{a}\left(800 \mathrm{mg}, 4.76 \mathrm{mmol}\right.$ ) was dissolved in $\mathrm{CH}_{2} \mathrm{Cl}_{2}$ $(8.4 \mathrm{ml})$ under inert atmosphere and pyridine $(2.6 \mathrm{ml})$ was added to the reaction mixture. The reaction mixture was then cooled to $-10{ }^{\circ} \mathrm{C}$ and a solution of pivaloyl chloride $(642 \mathrm{mg}$, $5.30 \mathrm{mmol})$ in $\mathrm{CH}_{2} \mathrm{Cl}_{2}(0.7 \mathrm{ml})$ was added drop wise to the reaction mixture, which was allowed to reach RT. After stirring for $48 \mathrm{~h}$, the solvent was evaporated and the crude crystals were purified by two consecutive flash chromatography treatments using cyclohexane-EtOAc (7:3) and cyclohexane$\mathrm{Et}_{2} \mathrm{O}(6: 1)$ as eluents. This procedure yielded 17a as a white solid (803 mg, 67\%). M.p. 64-67 ${ }^{\circ} \mathrm{C} .-{ }^{1} \mathrm{H}$ NMR $\left(250 \mathrm{MHz}, \mathrm{DMSO}-d_{6}\right): \delta=1.31(\mathrm{~s}, 9 \mathrm{H}, 3 \times \mathrm{Me}), 3.77-3.91$ (s (app. d), $3 \mathrm{H}, \mathrm{COOMe}), 6.97-7.71\left(\mathrm{~m}, 3 \mathrm{H}, 3 \times \mathrm{H}_{\mathrm{ar}}\right), 10.52$ (bs, $1 \mathrm{H}, \mathrm{OH}) .-{ }^{13} \mathrm{C}\left\{{ }^{1} \mathrm{H}\right\}$ NMR $\left(62.9 \mathrm{MHz}, \mathrm{DMSO}-d_{6}\right)$ : $\delta=26.74(4 \times \mathrm{Me}), 38.38(\mathrm{COOMe}), 52.61\left(\mathrm{C}_{\mathrm{q}}\right), 118.83$, $120.49,125.86,126.97,128.62,139.06,152.10,168.96$ (all $\mathrm{C}_{\mathrm{ar}}$ and $\left.2 \times \mathrm{C}=\mathrm{O}\right), 168.96(\mathrm{C}=\mathrm{O}) .-\mathrm{MS}: m / z=252\left[\mathrm{M}^{+}\right]$, 168, 136 (100\%), 107, 85, 69, 57, 41.

Methyl 2-hydroxy-4-pivaloyloxybenzoate (17b): Prepared by the procedure used for compound 17a but with the methyl benzoate $15 \mathbf{b}(500 \mathrm{mg}, 2.97 \mathrm{mmol})$ as starting material. Compound 17b was isolated as a white solid $(245 \mathrm{mg}$, 33\%). M.p. $71-73{ }^{\circ} \mathrm{C} .-{ }^{1} \mathrm{H}$ NMR $(250 \mathrm{MHz}$, DMSO$\left.d_{6}\right): \delta=1.30(\mathrm{~s}, 9 \mathrm{H}, 3 \times \mathrm{Me}), 3.89(\mathrm{~s}, 3 \mathrm{H}, \mathrm{COOMe})$, $6.69-6.77\left(\mathrm{t}, 2 \mathrm{H}, 2 \times \mathrm{H}_{\mathrm{ar}}\right), 7.80-7.85\left(\mathrm{~d}, 1 \mathrm{H}, \mathrm{H}_{\mathrm{ar}}\right)$. ${ }^{13} \mathrm{C}\left\{{ }^{1} \mathrm{H}\right\} \mathrm{NMR}\left(62.9 \mathrm{MHz}, \mathrm{DMSO}-d_{6}\right): \delta=26.50(4 \times \mathrm{Me})$,
38.52 (COOMe), $52.32\left(\mathrm{C}_{\mathrm{q}}\right), 110.32,110.83,113.20,131.19$, 155.91, 160.93, 168.36, 175.57 (all $\mathrm{C}_{\mathrm{ar}}$ and $2 \times \mathrm{C}=\mathrm{O}$ ). $-\mathrm{MS}$ : $m / z=252\left[\mathrm{M}^{+}\right], 221,168,136(100 \%), 108,95,85,69$, $57,41$.

Methyl 2-hydroxy-5-pivaloyloxybenzoate (17c): Prepared by the procedure used for compound $\mathbf{1 7} \mathbf{a}$ but with the methyl benzoate $16 \mathbf{c}(650 \mathrm{mg}, 3.87 \mathrm{mmol})$ as starting material. Compound 17c was isolated as a white solid $(98 \mathrm{mg}, 10 \%)$. ${ }^{1} \mathrm{H}$ NMR $\left(250 \mathrm{MHz}, \mathrm{DMSO}-d_{6}\right): \delta=1.28(\mathrm{~s}, 9 \mathrm{H}, 3 \times \mathrm{Me})$, 3.88 (s, $3 \mathrm{H}, \mathrm{COOMe}), 6.99-7.03\left(\mathrm{~d}, 1 \mathrm{H}, \mathrm{H}_{\mathrm{ar}}\right), 7.25-7.29$ (m, $\left.1 \mathrm{H}, \mathrm{H}_{\mathrm{ar}}\right), 7.29-7.43\left(\mathrm{~m}, 1 \mathrm{H}, \mathrm{H}_{\mathrm{ar}}\right), 10.50$ (bs, $1 \mathrm{H}$, OH). - MS: $m / z=252\left[\mathrm{M}^{+}\right], 221,205,193,177,168$, 136 (100\%), 108, 85, 77, 69, 57, 50, 41.

Methyl 2-methoxy-3-pivaloyloxybenzoate (18a): The diester 17a (400 mg, $1.59 \mathrm{mmol})$ was dissolved in dry DMF $(2 \mathrm{ml})$ and $\mathrm{K}_{2} \mathrm{CO}_{3}(242 \mathrm{mg}, 1.90 \mathrm{mmol})$ was added in 2 portions, followed by MeI $(0.128 \mathrm{ml}, 2.06 \mathrm{mmol})$. The resulting suspension was stirred vigorously at $35^{\circ} \mathrm{C}$ for $90 \mathrm{~min}$. The reaction mixture was then cooled to RT. The solid was removed by filtration and the solvent was evaporated to give an oil. The solid was dissolved in water $(10 \mathrm{ml})$ and added to the oil. The water phase was extracted with $\mathrm{Et}_{2} \mathrm{O}(3 \times 10 \mathrm{ml})$. The combined organic layers were washed with water and brine. The organic layer was then dried over $\mathrm{MgSO}_{4}$ and the solvent was evaporated to give 18a as a pale yellow oil (288 mg, $70 \%$ ). $-{ }^{1} \mathrm{H}$ NMR $\left(250 \mathrm{MHz}, \mathrm{DMSO}-d_{6}\right): \delta=1.31-1.33$ (s (app. d), $9 \mathrm{H}, 3 \times \mathrm{CH}_{3}$ ), 3.72 (s, $\left.3 \mathrm{H}, \mathrm{OMe}\right), 3.85$ (s, $3 \mathrm{H}$, COOMe), $7.21-7.39\left(\mathrm{~m}, 2 \mathrm{H}, 2 \times \mathrm{H}_{\mathrm{ar}}\right), 7.60-7.63(\mathrm{~m}, 1 \mathrm{H}$, $\left.\mathrm{H}_{\mathrm{ar}}\right) .-{ }^{13} \mathrm{C}\left\{{ }^{1} \mathrm{H}\right\}$ NMR (62.9 MHz, DMSO- $\left.d_{6}\right): \delta=26.62$ $(4 \times \mathrm{Me}), 38.37(\mathrm{COOMe}), 52.19\left(\mathrm{C}_{\mathrm{q}}\right), 61.95(\mathrm{OMe}), 124.02$, 125.83, 127.35, 127.95, 144.54, 151.01, 165.21, 175.70 (all $\mathrm{C}_{\mathrm{ar}}$ and $\left.2 \times \mathrm{C}=\mathrm{O}\right) .-\mathrm{MS}: m / z=266\left[\mathrm{M}^{+}\right], 235,219,182$, 164, 150, 136, 121, 107, 93, 85, 77, 65, 57 (100\%), 41.

Methyl 2-methoxy-4-pivaloyloxybenzoate (18b): Produced by the procedure employed for compound 18a but with the diester 17b (200 mg, $0.793 \mathrm{mmol}$ ) as starting material. Compound 18b was isolated as a colourless oil $(160 \mathrm{mg}, 76 \%)$. ${ }^{1} \mathrm{H}$ NMR $\left(250 \mathrm{MHz}, \mathrm{DMSO}-d_{6}\right): \delta=1.30(\mathrm{~s}, 9 \mathrm{H}, 3 \times \mathrm{Me})$, 3.78 (s, $3 \mathrm{H}, \mathrm{COOMe}), 3.82$ (s, $3 \mathrm{H}, \mathrm{OMe}), 6.74-6.78$ (m, $\left.1 \mathrm{H}, \mathrm{H}_{\mathrm{ar}}\right), 6.91-6.92\left(\mathrm{~m}, 1 \mathrm{H}, \mathrm{H}_{\mathrm{ar}}\right), 7.70-7.73(\mathrm{~m}, 1 \mathrm{H}$, $\left.\mathrm{H}_{\mathrm{ar}}\right) .-{ }^{13} \mathrm{C}\left\{{ }^{1} \mathrm{H}\right\}$ NMR $\left(62.9 \mathrm{MHz}, \mathrm{DMSO}-d_{6}\right): \delta=26.56$ $(4 \times \mathrm{Me}), 38.52(\mathrm{COOMe}), 51.72\left(\mathrm{C}_{\mathrm{q}}\right), 56.06(\mathrm{OMe}), 106.45$, 113.35, 117.16, 131.70, 154.65, 159.35, 165.31, 175.71 (all $\mathrm{C}_{\mathrm{ar}}$ and $\left.2 \times \mathrm{C}=\mathrm{O}\right)$. $-\mathrm{MS}: m / z=266\left[\mathrm{M}^{+}\right], 235,223,182$, 165, 151, 136, 122, 107, 93, 85, 77, 65, 57 (100\%), 41.

Methyl 2-methoxy-5-pivaloyloxybenzoate (18c): Synthesized by the procedure used for compound 18a but with the diester 17c (100 mg, $0.39 \mathrm{mmol})$ as starting material. Compound 18c was isolated as a colourless oil $(74 \mathrm{mg}, 70 \%)$. ${ }^{1} \mathrm{H}$ NMR $\left(250 \mathrm{MHz}, \mathrm{DMSO}-d_{6}\right): \delta=1.28(\mathrm{~s}, 9 \mathrm{H}, 3 \times \mathrm{Me})$, 3.78 (s, $3 \mathrm{H}, \mathrm{COOMe}), 3.82$ (s, $3 \mathrm{H}, \mathrm{OMe}), 7.16-7.36(\mathrm{~m}$, $\left.3 \mathrm{H}, 3 \times \mathrm{H}_{\mathrm{ar}}\right) \cdot-{ }^{13} \mathrm{C}\left\{{ }^{1} \mathrm{H}\right\} \mathrm{NMR}\left(62.9 \mathrm{MHz}, \mathrm{DMSO}-d_{6}\right): \delta=$ $26.65(4 \times \mathrm{Me}), 38.52(\mathrm{COOMe}), 51.97\left(\mathrm{C}_{\mathrm{q}}\right), 56.14(\mathrm{OMe})$, 
$113.42,120.28,123.45,126.43,143.12,155.66,165.17$, 176.45 (all $\mathrm{C}_{\mathrm{ar}}$ and $2 \times \mathrm{C}=\mathrm{O}$ ). $-\mathrm{MS}: m / z=266\left[\mathrm{M}^{+}\right], 235$, 182 (100\%), 167, 149, 135, 121, 107, 93, 85, 77, 65, 57, 41.

Methyl 3-hydroxy-2-methoxybenzoate (3): The diester 18a (98 mg, $0.37 \mathrm{mmol}$ ) was dissolved in $\mathrm{MeOH}(3.7 \mathrm{ml}$ ) and $\mathrm{K}_{2} \mathrm{CO}_{3}(0.108 \mathrm{~g}, 0.78 \mathrm{mmol})$ was added to the reaction mixture that was stirred at room temperature for $3 \mathrm{~h}$. Then the liquid was decanted from the solid residue and the solvent was evaporated to give crude white crystals. The previous solid residue was dissolved in water $(3 \mathrm{ml})$ and $\mathrm{HCl}$ (37\%) was added until $\mathrm{pH}=2$. Then the aqueous solution was added to the crude white crystals and the mixture was extracted with $\mathrm{Et}_{2} \mathrm{O}(3 \times 5 \mathrm{ml})$. The combined organic layers were washed (water, brine) and dried $\left(\mathrm{MgSO}_{4}\right)$. The solvent was evaporated to give 3 as a colourless oil $(34 \mathrm{mg}$, $50 \%$ ). $-{ }^{1} \mathrm{H}$ NMR (250 MHz, DMSO- $\left.d_{6}\right): \delta=3.74$ (s, $3 \mathrm{H}$, COOMe), 3.80 (s, $3 \mathrm{H}, \mathrm{OMe}), 7.03\left(\mathrm{~m}, 3 \mathrm{H}, 3 \times \mathrm{H}_{\mathrm{ar}}\right.$ ), 9.64 (bs, $1 \mathrm{H}, \mathrm{OH}) .-{ }^{13} \mathrm{C}\left\{{ }^{1} \mathrm{H}\right\}$ NMR $\left(62.9 \mathrm{MHz}, \mathrm{DMSO}-d_{6}\right)$ : $\delta=51.82$ (COOMe), 60.51 (OMe), 119.87, 119.97, 123.79, 125.80, 146.62, 150.83, 166.20 (all $\mathrm{C}_{\mathrm{ar}}$ and $\mathrm{C}=\mathrm{O}$ ). $-\mathrm{MS}$ : $m / z(\%)=182(81)\left[\mathrm{M}^{+}\right], 164(24), 151(80), 136(43)$, 121 (100), 107 (62), 93 (12), 79 (12), 65 (16), 59 (2.4), 51 (14), 45 (3.8), 39 (6.7).

Methyl 4-hydroxy-2-methoxybenzoate (4): Prepared by the procedure used for compound $\mathbf{3}$ with the diester $\mathbf{1 8 b}$ (160 mg, $0.60 \mathrm{mmol}$ ) as starting material. Compound 4 was isolated as a white solid (51 mg, 46\%). M.p. 130$135{ }^{\circ} \mathrm{C} .-{ }^{1} \mathrm{H}$ NMR $\left(250 \mathrm{MHz}, \mathrm{DMSO}-d_{6}\right): \delta=3.70$ (s, $3 \mathrm{H}, \mathrm{COOMe}), 3.75$ (s, $3 \mathrm{H}, \mathrm{OMe}), 6.38-6.46$ (m, $\left.2 \mathrm{H}, 2 \times \mathrm{H}_{\mathrm{ar}}\right), 7.58-7.62\left(\mathrm{~m}, 1 \mathrm{H}, \mathrm{H}_{\mathrm{ar}}\right), 10.36$ (bs, $1 \mathrm{H}$, $\mathrm{OH}) .-{ }^{13} \mathrm{C}\left\{{ }^{1} \mathrm{H}\right\}$ NMR $\left(62.9 \mathrm{MHz}, \mathrm{DMSO}-d_{6}\right): \delta=51.10$ (COOMe), 55.38 (OMe), 99.45, 107.10, 109.85, 133.14, 160.84, 162.62, 165.31 (all $\mathrm{C}_{\mathrm{ar}}$ and $\mathrm{C}=\mathrm{O}$ ). $-\mathrm{MS}: \mathrm{m} / z(\%)=$ 182 (32) $\left[\mathrm{M}^{+}\right], 151$ (100), 136 (5.2), 121 (12), 108 (12), 93 (5.7), 65 (5.7), 53 (5.3), 44 (0.4), 39 (5.7).

Methyl 5-hydroxy-2-methoxybenzoate (5): Prepared by the procedure used for compound $\mathbf{3}$ but with the diester $\mathbf{1 8 c}$ (288 $\mathrm{mg}, 1.08 \mathrm{mmol}$ ) as starting material. Purification of the crude product by flash chromatography on silica gel using cyclohexane-EtOAc (3:1) as eluent yielded $\mathbf{5}$ as a slightly yellow oil (93 mg, 50\%). - ${ }^{1} \mathrm{H}$ NMR $\left(250 \mathrm{MHz}, \mathrm{CDCl}_{3}\right)$ : $\delta=3.83$ (s (app. d), $3 \mathrm{H}, \mathrm{COOMe}$ ), 3.88 (s (app. d), $3 \mathrm{H}$, $\mathrm{OMe}), 6.83-6.98\left(\mathrm{~m}, 2 \mathrm{H}, 2 \times \mathrm{H}_{\mathrm{ar}}\right), 7.24-7.34(\mathrm{~m}, 1 \mathrm{H}$, $\left.\mathrm{H}_{\mathrm{ar}}\right) .-{ }^{13} \mathrm{C}\left\{{ }^{1} \mathrm{H}\right\}$ NMR $\left(62.9 \mathrm{MHz}, \mathrm{CDCl}_{3}\right): \delta=52.25$ (COOMe), $56.63(\mathrm{OMe}), 113.89,118.12,120.71,122.48$, 149.22, 153.35, $166.86\left(\right.$ all $\mathrm{C}_{\mathrm{ar}}$ and $\left.\mathrm{C}=\mathrm{O}\right) .-\mathrm{MS}: \mathrm{m} / z(\%)=$ $182(75)\left[\mathrm{M}^{+}\right], 167$ (6.7), 151 (100), 136 (17), 121 (15), 108 (21), 93 (20), 80 (9), 65 (18), 52 (15), 44 (5.7).

Characterization of commercially available isomers, all purchased from Aldrich.

Methyl 2-hydroxy-4-methoxybenzoate (6): M.p. 50$53{ }^{\circ} \mathrm{C}$. $-{ }^{1} \mathrm{H}$ NMR $\left(500.14 \mathrm{MHz}, \mathrm{DMSO}-d_{6}\right): \delta=3.81$ (s, $3 \mathrm{H}, \mathrm{COOMe}$ ), 3.87 (s, $3 \mathrm{H}, \mathrm{OMe}$ ), 6.52-6.54 (m, $\left.2 \mathrm{H}, 2 \times \mathrm{H}_{\mathrm{ar}}\right), 7.71-7.73\left(\mathrm{~d}, 1 \mathrm{H}, \mathrm{H}_{\mathrm{ar}}\right), 10.78$ (bs, $1 \mathrm{H}$, $\mathrm{OH}) .-{ }^{13} \mathrm{C}\left\{{ }^{1} \mathrm{H}\right\}$ NMR $\left(125.76 \mathrm{MHz}, \mathrm{DMSO}-d_{6}\right): \delta=53.06$ (COOMe), 56.49 (OMe), 101.84, 106.15, 108.32, 132.21, 163.49, 166.11, $170.25\left(\right.$ all $\mathrm{C}_{\mathrm{ar}}$ and $\left.\mathrm{C}=\mathrm{O}\right) .-\mathrm{MS}: m / z(\%)=$ $182(40)\left[\mathrm{M}^{+}\right], 168$ (2), 150 (100), 139 (3.5), 122 (57), 107 (28), 95 (10), 79 (18), 63 (5), 51 (7.5).

Methyl 3-hydroxy-4-methoxybenzoate (7): M.p. $64-$ $67{ }^{\circ} \mathrm{C} .-{ }^{1} \mathrm{H}$ NMR $\left(500.14 \mathrm{MHz}, \mathrm{DMSO}-d_{6}\right): \delta=3.79$ (s, $3 \mathrm{H}, \mathrm{COOMe}), 3.84$ (s, $3 \mathrm{H}, \mathrm{OMe}), 7.01-7.04\left(\mathrm{~d}, 1 \mathrm{H}, \mathrm{H}_{\mathrm{ar}}\right.$ ), $7.37-7.40\left(\mathrm{~d}, 1 \mathrm{H}, \mathrm{H}_{\mathrm{ar}}\right), 7.43-7.47\left(\mathrm{dd}, 1 \mathrm{H}, \mathrm{H}_{\mathrm{ar}}\right), 9.48$ (bs, $1 \mathrm{H}, \mathrm{OH}) .-{ }^{13} \mathrm{C}\left\{{ }^{1} \mathrm{H}\right\}$ NMR $(125.76 \mathrm{MHz}$, DMSO$\left.d_{6}\right): \delta=52.62(\mathrm{COOMe}), 56.47(\mathrm{OMe}), 112.28,116.56$, 122.35, 122.74, 147.13, 152.78, $166.92\left(\right.$ all $\mathrm{C}_{\mathrm{ar}}$ and $\left.\mathrm{C}=\mathrm{O}\right)$. MS: $m / z(\%)=182(54)\left[\mathrm{M}^{+}\right], 167$ (5), 151 (100), 139 (4), 123 (13), 108 (7.5), 95 (2), 79 (6), 65 (6), 51 (7), 39 (2.5).

Methyl 2-hydroxy-3-methoxybenzoate (8): M.p. 61.5$62.5{ }^{\circ} \mathrm{C} .-{ }^{1} \mathrm{H}$ NMR $\left(500.14 \mathrm{MHz}, \mathrm{DMSO}-d_{6}\right): \delta=3.81$ (s, $3 \mathrm{H}, \mathrm{COOMe}), 3.90$ (s, $3 \mathrm{H}, \mathrm{OMe}$ ), 6.88-6.90 (t, $1 \mathrm{H}$, $\left.\mathrm{H}_{\mathrm{ar}}\right), 7.22-7.24\left(\mathrm{~d}, 1 \mathrm{H}, \mathrm{H}_{\mathrm{ar}}\right), 7.35-7.36\left(\mathrm{~d}, 1 \mathrm{H}, \mathrm{H}_{\mathrm{ar}}\right), 10.50$ (bs, $1 \mathrm{H}, \mathrm{OH}) .-{ }^{13} \mathrm{C}\left\{{ }^{1} \mathrm{H}\right\}$ NMR $(125.76 \mathrm{MHz}$, DMSO$\left.d_{6}\right): \delta=53.40$ (COOMe), 56.78 (OMe), 113.89, 117.89, $119.69,121.63,149.13,151.37,170.50\left(\right.$ all $C_{a r}$ and $\left.\mathrm{C}=\mathrm{O}\right)$. MS: $m / z(\%)=182(58)\left[\mathrm{M}^{+}\right], 167$ (2), 150 (65), $136(7)$, 122 (100), 107 (28), 92 (18), 79 (13), 65 (9), 53 (11), 39 (5).

Methyl 2-hydroxy-5-methoxybenzoate (9): B.p. 235$240{ }^{\circ} \mathrm{C} .-{ }^{1} \mathrm{H}$ NMR $\left(500.14 \mathrm{MHz}, \mathrm{DMSO}-d_{6}\right): \delta=3.72(\mathrm{~s}$, $3 \mathrm{H}, \mathrm{COOMe}$ ), 3.89 (s, $3 \mathrm{H}, \mathrm{OMe}$ ), $6.91-6.93$ (dd, $1 \mathrm{H}, \mathrm{H}_{\mathrm{ar}}$ ), $7.13-7.16$ (dd, $\left.1 \mathrm{H}, \mathrm{H}_{\mathrm{ar}}\right), 7.21-7.22\left(\mathrm{~d}, 1 \mathrm{H}, \mathrm{H}_{\mathrm{ar}}\right), 10.09$ (bs, $1 \mathrm{H}, \mathrm{OH}) .-{ }^{13} \mathrm{C}\left\{{ }^{1} \mathrm{H}\right\}$ NMR (125.76 MHz, DMSO- $\left.d_{6}\right)$ : $\delta=53.30$ (COOMe), 56.41 (OMe), 112.97, 113.43, 119.36, 124.26, 152.56, 155.23, 169.90 (all $\mathrm{C}_{\mathrm{ar}}$ and $\mathrm{C}=\mathrm{O}$ ). - MS: $m / z(\%)=182(43)\left[\mathrm{M}^{+}\right], 167(2.5), 150(100), 135(15)$, 122 (20), 107 (30), 93 (7.5), 79 (27), 65 (5), 51 (10), 39 (2.5).

Methyl 4-hydroxy-3-methoxybenzoate (10): M.p. $69-$ $70{ }^{\circ} \mathrm{C} .-{ }^{1} \mathrm{H}$ NMR $\left(500.14 \mathrm{MHz}, \mathrm{DMSO}-d_{6}\right): \delta=3.80(\mathrm{~s}$, $3 \mathrm{H}, \mathrm{COOMe}$ ), 3.82 (s, $3 \mathrm{H}, \mathrm{OMe}), 6.86-6.88\left(\mathrm{~d}, 1 \mathrm{H}, \mathrm{H}_{\mathrm{ar}}\right.$ ), $7.44-7.45\left(\mathrm{~d}, 1 \mathrm{H}, \mathrm{H}_{\mathrm{ar}}\right), 7.46-7.48\left(\mathrm{dd}, 1 \mathrm{H}, \mathrm{H}_{\mathrm{ar}}\right), 9.96$ (bs, $1 \mathrm{H}, \mathrm{OH}) .-{ }^{13} \mathrm{C}\left\{{ }^{1} \mathrm{H}\right\}$ NMR $(125.76 \mathrm{MHz}$, DMSO$\left.d_{6}\right): \delta=52.58$ (COOMe), 56.47 (OMe), 113.34, 116.06, 121.31, 124.28, 148.22, 152.38, 166.93 (all $\mathrm{C}_{\mathrm{ar}}$ and $\left.\mathrm{C}=\mathrm{O}\right)$. MS: $m / z(\%)=182(55)\left[\mathrm{M}^{+}\right], 167(5), 151(100), 140(5)$, 124 (11), 108 (6), 93 (2), 79 (5), 65 (5), 51 (6), 39 (2.5).

\section{Bioassay}

The various esters were tested for antifeedant effect on the pine weevil Hylobius abietis (L.) (Coleoptera, Curculionidae). For each test, 40 pine weevils ( 20 females +20 males) were used. They were placed in separate Petri dishes provided with a pine twig prepared with delimited treatment and control areas. These pine twigs were enveloped in aluminium foil and two holes with a diameter of $5 \mathrm{~mm}$ and separated by $25 \mathrm{~mm}$ were punched in the foil with metal 
rings. After removal of the aluminium foil inside the rings, one of the two surfaces exposed was treated with $100 \mu \mathrm{l}$ of a $50 \mathrm{mM}$ methanol solution of the compound that was tested, and the other surface was treated with the same amount of methanol alone (control). The following day, after the solvent had evaporated, the metal rings were removed and the test started. After 6 and 24 hours it was recorded whether the pine weevil had started to feed on the treated and untreated surfaces. The antifeedant effect was expressed by means of the following index: $(C-T) \times 100 /(C+T)$, wherein $\mathrm{C}$ is the number of control surfaces with feeding marks and
$\mathrm{T}$ is the number of treated surfaces with feeding marks. It was tested if there was a statistic significant difference between treatment and control with a Fisher exact test of a $2 \times 2$ table.

\section{Acknowledgements}

This work has been supported financially by The University of Kalmar, by Robigus AB and by the Swedish Hylobius Research Program. Help from Professors Roland Isaksson and Ian Nicholls (both at the University of Kalmar) in the form of discussions is gratefully acknowledged.
[1] G. Örlander, U. Nilsson, Scand. J. For. Res. 14, 341 (1999).

[2] K. Bratt, K. Sunnerheim, H. Nordenhem, G. Nordlander, B. Långström, J. Chem. Ecol. 27, 2253 (2001).

[3] G. Nordlander, H. Nordenhem, A.-K. Borg-Karlson, R. Unelius, Swedish and PCT Patent Application WO 0056152 A1, 2000.

[4] a) For 1 see: S.E. Maier, S. Kühnert, Org. Lett. 4, 643 (2002); b) for 2 see: T. K. Chakrabotry, G. Venkat Reddy, J. Org. Chem. 57, 5462 (1992); c) for 3 see: R. S. Coleman, E. B. Grant, J. Am. Chem. Soc. 117, 10889 (1995). I. Churcher, D. Hallet, P. Magnus, Tetrahedron 55, 1597 (1999); d) for 4 see: M. I. Bell, J. M. Erb, R. M. Freidinger, S. N. Gallicchio, J. P. Guare,
M. T. Guidotti, R. A. Halpin, D. W. Hobbs, C. F. Homnick, M. S. Kuo, E. V. Lis, D. J. Mathre, S. R. Michelson, J.M. Pawluczyk, D. J. Pettibone, D.R. Reiss, S. Vickers, P. D. Williams, C. J. Woyden, J. Med. Chem. 41, 2146 (1998).

[5] L. M. Harwood, J. Chem. Soc., Chem. Commun. 9, 530 (1983).

[6] J. Dornhagen, H.-D. Scharf, Tetrahedron 1, 173 (1985).

[7] F. W. McLafferty, Interpretation of Mass Spectra, 3rd Ed. University Science Books, Mills Valley California (1980).

[8] P. Baeckström, K. Stridh, L. Li, T. Norin, Acta Chem. Scand. B41, 442 (1987). 